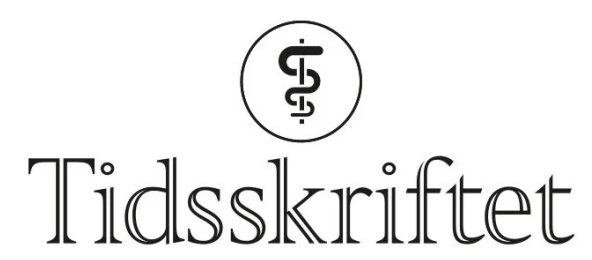

DEN NORSKE LEGEFORENING

\title{
Har Tidsskriftet for lang publiseringstid?
}

KOMMENTAR

\section{OLAV F. MÜNTER SELLEVOLD}

Email: olav.sellevold@ntnu.no

St. Olavs hospital

7006 Trondheim

og

Institutt for sirkulasjon og bildediagnostikk

Det medisinske fakultet

Norges teknisk-naturvitenskapelige universitet

\section{DAG BRATLID}

Institutt for laboratoriemedisin, barne- og kvinnesykdommer Det medisinske fakultet

Norges teknisk-naturvitenskapelige universitet

og

Barne- og ungdomsklinikken

St. Olavs hospital

Tidsskriftet er et viktig forum for faglig oppdatering for norske leger og bør stimulere til bidrag fra erfarne kolleger. Publiseringsprosessen må være rask og strømlinjeformet. I en analyse av aksept og publiseringstider finner vi generelt altfor lang publiseringstid med stor og uakseptabel variasjon. De medisinske redaktører er viktige premissgivere for publiseringsprosessen. Tidsskriftet bør legge vekt på veiledning i pedagogisk fremstilling av stoffet og mindre på språklig petitesse.

Forfattere av vitenskapelige publikasjoner og redaktører av vitenskapelige tidsskrifter har et felles ønske om at publiseringstiden skal være så kort som mulig. Den redaksjonelle prosess forutsetter et godt samarbeid mellom forfatter, fagfelle (referee) og redaksjon. Gode fagfeller er avgjørende for kvalitet, den medisinske redaktør på sin side skal organisere fagfellene og avlaste sjefredaktør, mens den viktigste faktor for et godt tidsskrift 
er at forfattere sender inn gode manuskripter. Hensikten med denne artikkelen er å belyse publiseringsprosessen i Tidsskriftet for å sikre at forfattere opplever det som interessant å publisere i Tidsskrift for Den norske legeforening (Tidsskriftet).

Både forfatter og leser ønsker at tiden det tar fra innlevering av manuskript til det er ferdig publisert er så kort som mulig, slik at Tidsskriftet kan levere «ferskvare». Publiseringstiden i Tidsskriftet er etter vår mening for lang. Dette synes å være en utbredt oppfatning også hos andre forfattere og har kommet til uttrykk i Tidsskriftet (1). Ved flere artikler har Tidsskriftet beklaget lang publiseringstid og angitt at «det skyldes ikke forfatterne» $(\underline{2}, 3)$. Nylig fikk en artikkel også etterskrift om at noe av grunnlaget for artikkelens diskusjon (anbefalinger fra WHO) var blitt endret (foreldet) i løpet av den redaksjonelle prosessen (4).

På nyåret 2010 sendte vi uavhengig av hverandre inn hvert vårt debattinnlegg til Tidsskriftet om dette emnet. Redaksjonen har bedt oss samordne disse til én artikkel. Vi har gått igjennom Tidsskriftets publiseringsprosess basert på egne erfaringer og på en gjennomgang av de artikkeldata som Tidsskriftet oppgir. Den samme prosessen i flere internasjonale fagtidsskrifter er brukt som sammenlikning.

\section{Materiale og metode}

Det er gjort to studier. I begge studiene ble den redaksjonelle prosess delt i aksepttid (tid fra mottatt til akseptert manuskript), trykketid (tid fra akseptert manuskript til publisert artikkel) og publiseringstid (tid fra mottatt manuskript til publisert artikkel). I studie 1 ble publiseringstiden i Tidsskriftet sammenliknet med Acta Paediatrica og Pediatric Research. Alle originalartikler, oversiktsartikler og fagartikler i Tidsskriftet f.o.m. nr. 18/20og t.o.m. nr. 3/2010 under hovedoverskriften Medisin og vitenskap, til sammen 65 artikler, ble gjennomgått. Fra Acta Paediatrica ble samtlige 37 tilsvarende artikler i februarnummeret 2009 vurdert, og fra Pediatric Research ble til sammen 39 artikler fra november og desember 2009 inkludert. Tidsskriftet angir publiseringsdato på den trykte utgaven mens Acta Paediatrica og Pediatric Research kommer ut månedlig uten angitt dato.

Utgivelsestidspunktet er vanligvis i slutten av måneden. Siste dato i forutgående måned ble derfor brukt som publiseringstidspunkt for disse to tidsskriftene. I Tidsskriftet og i Pediatric Research er det for den enkelte artikkel bare angitt aksepttid, mens trykketiden kan beregnes fra oppgitte data. Acta Paediatrica oppgir i tillegg når det reviderte manuskript ble mottatt, slik at man kan beregne tiden forfatterne bruker på revisjonen samt den tiden redaksjonen bruker på å akseptere det reviderte manuskript (tab 1$)$.

I studie 2 ble artikler i Tidsskriftet 2009 fra nr. 1-4 og nr. 16-20 under hovedoverskriften Medisin og vitenskap analysert, til sammen 80 artikler. I denne studien ble publiseringstiden analysert separat for ulike typer artikler (Noe å lære av, Aktuelt osv.) og ble videre analysert i relasjon til de medisinske redaktører som behandlet artiklene. Data for begge studiene ble analysert gjennom SPSS versjon 16/17.

\section{Tabell 1}

Sammenlikning av publiseringstider i dager for fagartikler publisert i Tidsskrift for Den norske legeforening (Tidsskriftet) i 2009/2010, Acta Paediatrica i 2009 og Pediatric Research i 2009. Gjennomsnittlig og median tidsbruk samt spredning er angitt i dager for aksepttid (tid fra innsendt til akseptert manus), trykketid (tid fra akseptert manus til trykt artikkel) og publiseringstid (tid fra innsendt manus til trykt artikkel). For Acta Paediatrica er det også angitt tid fra mottatt revisjon til akseptert artikkel (studie 1)

\begin{tabular}{|ccc|}
\hline Tidsskriftet & Acta Paediatrica & Pediatric Research \\
\hline $\begin{array}{c}\text { Gj.snitt/median } \\
\text { (spredning) }\end{array}$ & $\begin{array}{c}\text { Gj.snitt/median } \\
\text { (spredning) }\end{array}$ & $\begin{array}{c}\text { Gj.snitt/median } \\
\text { (spredning) }\end{array}$ \\
\hline
\end{tabular}




\begin{tabular}{|lccc|}
\hline & Tidsskriftet & Acta Paediatrica & Pediatric Research \\
\hline & $\begin{array}{c}\text { Gj.snitt/median } \\
\text { (spredning) }\end{array}$ & $\begin{array}{c}\text { Gj.snitt/median } \\
\text { (spredning) }\end{array}$ & $\begin{array}{c}\text { Gj.snitt/median } \\
\text { (spredning) }\end{array}$ \\
\hline Antall artikler vurdert & 65 & 37 & 39 \\
\hline Tid til mottatt revisjon & & $98 / 86(18-249)$ & \\
\hline $\begin{array}{l}\text { Tid fra mottatt revisjon til } \\
\text { akseptert manuskript }\end{array}$ & & $28 / 14(1-173)$ & \\
\hline Aksepttid & $281 / 236(44-840)$ & $126 / 123(19-315)$ & $99 / 101(30-197)$ \\
\hline Trykketid & $106 / 91(42-371)$ & $148 / 143(86-187)$ & $115 / 111(97-197)$ \\
\hline Publiseringstid & $385 / 319(93-931)$ & $269 / 261(131-45)$ & $214 / 214(155-294)$ \\
\hline
\end{tabular}

\section{Resultater}

Tabell 1 (studie 1) viser at Tidsskriftet har vesentlig lengre gjennomsnittlig aksepttid (281 dager) enn både Acta Paediatrica (126 dager) og Pediatric Research (99 dager). Dette medfører at også den gjennomsnittlige publiseringstid blir svært lang i Tidsskriftet (385 dager) i forhold til Acta Paediatrica (269 dager) og Pediatric Research (214 dager). I Tidsskriftet er bare $25 \%$ av manuskriptene akseptert innen 181 dager, og $25 \%$ av manuskriptene er fortsatt ikke akseptert nesten ett år etter at de er sendt inn (353 dager, data ikke vist). Derimot er den gjennomsnittlige trykketid heller kortere i Tidsskriftet (106 dager) enn i Acta Paediatrica (148 dager) og Pediatric Research (115 dager). Tabellen viser også at det i Tidsskriftet er stort avvik mellom gjennomsnittlig og median tidsbruk, mens gjennomsnittlig og median tidsbruk for de to andre tidsskriftene er nærmest identiske.

Tallene fra Acta Paediatrica viser at gjennomsnittlig revisjonstid er noe lengre enn de $\emptyset$ nskede go dagene, men over halvparten av revisjonene kommer inn til redaksjonen før 90 dager (median 86 dager) (tab 1). Samtidig er prosessen frem til aksept av manus overraskende kort, i gjennomsnitt 28 dager med en median verdi på 14 dager og spredning 1-173 dager. Dette tilsier at halvparten av alle manuskripter faktisk er akseptert innen 14 dager etter at det reviderte manuskriptet er mottatt i redaksjonen.

Tabell 2 (studie 2) viser publikasjonstid og trykketid i for ulike typer artikler. Kronikk hadde kortest aksepttid, mens Legemidler i praksis hadde kortest trykketid. For alle typer artikler var spredningen stor, og for mange artikler i hver gruppe var både aksepttid og trykketid svært lang. Tabell 3 (studie 2) viser at det er betydelig forskjell $i$ aksepttid hos den enkelte medisinsk redaktør samt mellom de ulike medisinske redaktører. Bortsett fra redaktør R1 og R2, som bare har behandlet hhv. to og tre artikler, har alle redaktørene vært ansvarlig for artikler med svært lang aksepttid. To redaktører som kun hadde én artikkel hver, der aksepttid var hhv. 509 og 717 dager, er ikke tatt med i tabell 3.

\section{Tabell 2}

Aksepttid (tid fra innsendt til akseptert manus) og trykketid (tid fra akseptert manus til trykt artikkel) i dager for 80 artikler publisert i 2009 i Tidsskrift for Den norske legeforening, fordelt etter type artikkel (studie 2)

\begin{tabular}{|c|c|c|c|c|c|c|c|}
\hline \multirow{2}{*}{ Artikkeltype } & \multirow{2}{*}{\multicolumn{3}{|c|}{ Legemidler }} & \multirow{2}{*}{\multicolumn{3}{|c|}{$\begin{array}{c}\text { Noe } \\
\text { å lære }\end{array}$}} & \\
\hline & & & & & & & Aktuelt \\
\hline
\end{tabular}




\begin{tabular}{|c|c|c|c|c|c|c|c|c|}
\hline & & & Legemidles & & & $\begin{array}{l}\text { Noe } \\
\text { å lære }\end{array}$ & & \\
\hline Artikkeltyp & & Kronikk & i praksis & Oversikt & Tema & av & Original & Aktuelt \\
\hline $\begin{array}{l}\text { Antall } \\
\text { artikler }\end{array}$ & & 8 & 5 & 17 & 12 & 10 & 18 & 10 \\
\hline Aksepttid & $\begin{array}{l}\text { Gj.snitt } \pm \\
\text { SD }\end{array}$ & $\begin{array}{c}137 \pm \\
101\end{array}$ & $181 \pm 57$ & $\begin{array}{c}215 \pm \\
136\end{array}$ & $\begin{array}{c}193 \pm \\
69\end{array}$ & $\begin{array}{c}207 \pm \\
196\end{array}$ & $215 \pm 114$ & $\begin{array}{c}338 \pm \\
132\end{array}$ \\
\hline & $\begin{array}{l}\text { Median } \\
\text { (spredning) }\end{array}$ & $\begin{array}{c}109 \\
(40- \\
304)\end{array}$ & $\begin{array}{c}158(138- \\
279)\end{array}$ & $\begin{array}{c}182 \\
(46- \\
595)\end{array}$ & $\begin{array}{c}211 \\
(92- \\
329)\end{array}$ & $\begin{array}{c}195(2- \\
717)\end{array}$ & $\begin{array}{c}242 \\
(132- \\
509)\end{array}$ & $\begin{array}{c}333 \\
(197- \\
583)\end{array}$ \\
\hline Trykketid & $\begin{array}{l}\text { Gj.snitt } \pm \\
\text { SD }\end{array}$ & $\begin{array}{c}105 \pm \\
79\end{array}$ & $71 \pm 24$ & $128 \pm 51$ & $\begin{array}{c}88 \pm \\
64\end{array}$ & $\begin{array}{c}137 \pm \\
74\end{array}$ & $114 \pm 142$ & $121 \pm 40$ \\
\hline & $\begin{array}{l}\text { Median } \\
\text { (spredning) }\end{array}$ & $\begin{array}{c}87(37- \\
277)\end{array}$ & $\begin{array}{c}82(35- \\
97)\end{array}$ & $\begin{array}{c}117(40- \\
239)\end{array}$ & $\begin{array}{c}49 \\
(41- \\
222)\end{array}$ & $\begin{array}{c}117 \\
(35- \\
241)\end{array}$ & $\begin{array}{c}114(54- \\
225)\end{array}$ & $\begin{array}{c}114 \\
(63-213\end{array}$ \\
\hline
\end{tabular}

\section{Tabell 3}

Aksepttid (tid fra innsendt til akseptert manus) i dager for 78 artikler publisert i Tidsskrift for Den norske legeforening i 2009, fordelt etter medisinsk redaktør (R1 til R9) (studie 2)

\begin{tabular}{|c|c|c|c|c|c|c|c|c|c|}
\hline Redaktør & R1 & $\mathbf{R 2}$ & $\mathrm{R}_{3}$ & R4 & $\mathrm{R}_{5}$ & R6 & $\mathrm{R}_{7}$ & R8 & R9 \\
\hline $\begin{array}{l}\text { Antall } \\
\text { artikler }\end{array}$ & 2 & 3 & 13 & 6 & 18 & 10 & 13 & 3 & 10 \\
\hline $\begin{array}{l}\text { Gj.snitt } \pm \\
\text { SD }\end{array}$ & $\begin{array}{c}101 \pm \\
45\end{array}$ & $\begin{array}{c}129 \pm \\
75\end{array}$ & $\begin{array}{c}148 \pm \\
60\end{array}$ & $\begin{array}{c}177 \pm \\
43\end{array}$ & $\begin{array}{c}183 \pm \\
93\end{array}$ & $\begin{array}{c}188 \pm \\
53\end{array}$ & $\begin{array}{c}238 \pm \\
76\end{array}$ & $\begin{array}{c}304 \pm \\
106\end{array}$ & $\begin{array}{c}439 \pm \\
98\end{array}$ \\
\hline $\begin{array}{l}\text { Median } \\
\text { (spredning) }\end{array}$ & $\begin{array}{c}101 \\
(69- \\
132)\end{array}$ & $\begin{array}{c}148 \\
(46- \\
193)\end{array}$ & $\begin{array}{c}152 \\
(43- \\
279)\end{array}$ & $\begin{array}{c}197 \\
(110- \\
218)\end{array}$ & $\begin{array}{c}195 \\
(2- \\
399)\end{array}$ & $\begin{array}{c}186 \\
(106- \\
271)\end{array}$ & $\begin{array}{c}231 \\
(92- \\
393)\end{array}$ & $\begin{array}{c}312 \\
(195- \\
406)\end{array}$ & $\begin{array}{c}404 \\
(304- \\
595)\end{array}$ \\
\hline
\end{tabular}

\section{Diskusjon}

\section{HAR TIDSSKRIFTET FOR LANG PUBLIKASJONSTID?}

Vi har begge i en årrekke vært involvert både som forfattere og fagfeller i nasjonale og internasjonale tidsskrifter, en av oss (OFMS) også som redaktør i en rekke internasjonale fagfellebaserte tidsskrifter. Vår erfaring er at mange forfattere og forskere vil ha stor nytte av og ofte være avhengig av redaksjonell hjelp for at et manuskript skal bli til en god artikkel. Også erfarne skribenter kan iblant ha nytte av forslag til å bedre fremstillingen og poengtere viktige forhold. Den gode fagfelle og medisinske redaktør kjenner fagområdet og kan komme med forslag til nye analyser eller endringer i presentasjonen av data. Dette vil ofte bedre tilgjengeligheten for kolleger som ikke arbeider i det feltet som artikkelen omhandler.

For de tre tidsskriftene i studie 1 er det like krav om at fagfellevurderingen skal ta mindre enn tre uker og at det reviderte manuskriptet må returneres innen go dager etter at den første tilbakemeldingen fra redaksjonen foreligger. Resultatene fra våre undersøkelser styrker likevel vår oppfatning av at Tidsskriftet har altfor lang publiseringstid, og at det 
derfor er grunn til å forbedre den redaksjonelle prosessen. Det er særlig aksepttiden som er for lang, noe som medfører at artiklene kan bli mindre aktuelle når de omsider trykkes.

Prosessen vil dessuten kunne trette ut både forfatter og redaktør. En av oss (OFMS) ble nylig invitert til å skrive en oversiktsartikkel i tre forskjellige tidsskrifter. Artikkelen i European Journal of Anaesthesiology (5) hadde aksepttid på 15 dager og trykketid på 41 dager, artikkelen i Current Opinion in Anaesthesiology (므) hadde aksepttid på sju dager og trykketid på 22 dager, mens artikkelen i Tidsskriftet (7.) hadde aksepttid på 447 dager og trykketid på 101 dager. Slike erfaringer stimulerer ikke til å prioritere faglig og vitenskapelig informasjon til kolleger gjennom Tidsskriftet.

Vi har ikke data som kan belyse fordeling av tidsbruk mellom medisinsk redaktør, fagfelle og forfatter. Noe av den lange aksepttiden kan også skyldes den enkelte forfatter og reflekteres sannsynligvis i den store forskjellen det er mellom gjennomsnittlige og mediane publiseringstider i Tidsskriftet i motsetning til i Acta Paediatrica og Pediatric Research (tab 1). De siste to er begge raske til å avvise mangelfulle eller svake manuskripter. Mange avvises også ut fra en ren redaksjonell vurdering uten å bli sendt til fagfeller. Redaksjonen i Tidsskriftet ser det nok i større grad som en oppgave å hjelpe slike manuskripter frem til publisering gjennom redaksjonell og annen bistand, slik det bl.a. er blitt uttrykt på de årlige møtene mellom redaksjonen og fagfellene. Dette kan medføre svært lang behandlingstid for noen manuskripter. Denne ekstrainnsatsen fra redaksjonens side må derfor vurderes opp mot nytten av å publisere manuskripter flere år etter at de ble sendt inn.

Det synes å være betydelige forskjeller i tidsbruk mellom de medisinske redaktører. Dette indikerer at noe av forsinkelsen kan ligge i den enkelte redaktørs arbeidsform ( tab 3). Det er lite sannsynlig at en medisinsk redaktør bare får tildelt langsomme forfattere eller velger trege fagfeller. Derimot kan det tenkes at de medisinske redaktørene ikke er like flinke til å følge opp forfattere og fagfeller som viser seg å være langsomme. Det må videre vurderes hvorvidt de medisinske redaktører er flinke nok til å skille i behandlingen av gode og dårlige manuskripter.

SPRÅK ELLER MEDISIN - FAG ELLER LAYOUT?

Etter vår oppfatning må fagfellenes vurderinger veie tyngst i vurderingen av et manuskript. Medisinsk redaktør må selvfølgelig vurdere hvordan ulike fagfellevurderinger skal håndteres og hvorvidt det er behov for å innhente ytterligere vurderinger. I tillegg skal medisinsk redaktør sikre at spesifikke redaksjonelle krav til tabeller, figurer, referanser osv. samt lengde på manuskriptet er oppfylt. Vi har snakket med en lang rekke kolleger om Tidsskriftet. Det er en utbredt oppfatning at redaksjonen bruker altfor mye tid og energi på forhold som ikke er relatert til forståelsen av artikkelens faglige innhold. Slik blir prosessen både uhensiktsmessig og langsom.

Figur 1 viser et eksempel på hvordan en manuskriptside (fra en oversiktsartikkel) (7.) kan se ut når teksten har vært gjennomgått av redaksjonen. Medisinsk redaktør kommenterer også formuleringer som oppfattes som uklare. Dette er velkommen og nyttig kritikk. Likevel er totalinntrykket av tilbakemeldingen først og fremst påpeking av forhold som har med språktone og språkbruk å gjøre. De språklige rettelsene, både ved første og andre revisjon, kan synes mer pedantiske enn det noen folkeskolelærer ville gjøre med en norsk stil. Dette stimulerer ikke forfatter til å klargjøre tekst eller forsterke pedagogiske poenger. Medisinsk redaktør (eller fagfelle) synes å ønske at artikkelen skrives i en språkdrakt som bestemmes av redaktør. Setningsbygning og ordvalg er en del av forfatterens identitet og bør ikke endres så fremt det ikke er direkte filologisk galt, eller at form og ordvalg kan føre til at det faglige innholdet misforstås. Medisinsk redaktør skal, dersom det er innen den enkeltes kompetanseområde, sette spørsmål ved faglige utsagn, diskutere sammenheng mellom resultat og konklusjoner og påpeke uklarheter - det er redaksjonens rett og plikt men språket må være forfatterens. 


\begin{tabular}{|c|c|}
\hline $\begin{array}{l}\text { Resultater. Det er lite evidens for bruk av spesielle anestesimetoder for bjertesyke } \\
\text { pasienter som skal til jkke-kardial kirurgi. Perioperativ betablokade er fordelaktiz. } \\
\text { til pasienter der man kan titrere blokeden over noe tid preoperativt. Akutt oppstart }\end{array}$ & 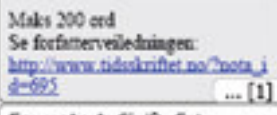 \\
\hline 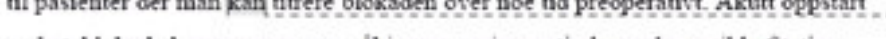 & Fonmatert: Skift: Fot \\
\hline av betablokade krever noye overvikjgę av perioperativ hemodynamikl, Statiner & Formatert: Soift: Fos \\
\hline bor vurderes for elektiv kirurgi. Det er ikke evidens for at det er nytrig a gjore & Merknad [t3]: Noe w $\zeta \ldots$... [2] \\
\hline koronarintervensjon for jkke-kardin kirurgi hos stabale pasienter. Ustabilt & Formatert: Skift: Fost \\
\hline koronarsyndrom má behandles. Ikke-kardjal kirurgi pă disse passentene má bare & Slettet: soe...el \\
\hline utfores pá vital indikasjon. God kjennskap til hemodynamikk og kirurgisk. & Fommatert: Utheving \\
\hline parofysiologi er nodvendig for à gi opeinal behandling. Det er ikke entydige & Merknad [t4]: Wallal? \\
\hline resultat for at nevrowsiale teknikker bedrer overlevelsen hos hiertepasienter etter & Slettet: $1 . . . . \ldots[4]$ \\
\hline akke-kardial,kirurgi. Derimot er teknikken overlegen til â redusere postoperativ & Slettet: noc....1...Nor ... [5] \\
\hline smerte. Perioperativ tromboseprofylakse oker faren for epiduralt hematom, og & $\begin{array}{l}\text { Merknad }[t 5]: \text { Opil eil ... [6] } \\
\text { Slettet: } x\end{array}$ \\
\hline systematisk oppfolging for diagnostikk og behandling er nodvendig. \$tabil & Slettet: soe-kxdell \\
\hline sirkulasjon, tilfredsstillende gksygenering god smertebehandling. . . ..... & Slettet: n \\
\hline tromboseprofylakse, enteral eraxering og tidlig mobilisering er faktore: & 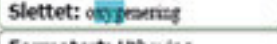 \\
\hline
\end{tabular}

\begin{tabular}{|c|c|}
\hline \multirow{2}{*}{ Preoperativ vurdering. } & \\
\hline & Slettet: til \\
\hline Pasienter med hjertesvikt kan ha hoyt niyg ay N-terminal B-tyee natriuretis. & 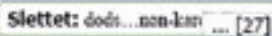 \\
\hline (pro-brain aatriuretic peptide (NT-BNP)) og brain natriuretic psptide (BNP & Slettet: E...modendise _.. [25] \\
\hline er korrelent med okt jisiko for dod ved ikke-kardial kinurgi. I en studie ble det & Slettet: soe-hastell \\
\hline perioperative forlop i en kohort pd over 159000 pasienter som giennomgikk ikke- & Slettet: lopet av irese - ... [29] \\
\hline 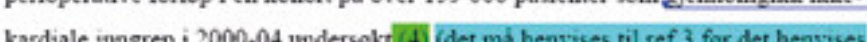 & Formatert \\
\hline kardiale ingrep 12000 -04 undersokt. 4 Id det ma benvises til ref 3 for det beavises & Slettet: vom \\
\hline til ref 4). Hjertesvikt som preoperativ diagnose var assosient med en mortalitet pá & Slettet: den _...ver aigif' _. [31] \\
\hline$\$ \%$, sammenlignet med $3,1 \%$ for pasienter med koronarsykdom som preopera & Slettet: and \\
\hline diagnose og $2,4 \%$ I gruppen som verken hadde koronarsykdom eller hjertesvikt & Slettet: i lourollewpen [5, A. \\
\hline 4). Man kan likevel jkke trekke noen sikker konklusion om at optimalisering av & Formatert \\
\hline & Slettet: Kercearsyldee _.. [33] \\
\hline hjertestikt (uklart uttrykt) med reduksjon av BNP (helst bare i & Slettet: \\
\hline bindestrekssanmenseminger) vil gi bedre prognose ettersom dette ikke var en & Slettet: diagose var o ... [34] \\
\hline intervensjonsstudie. Det synes imidlertid rimelig om nulig at utsette ikke-kardial & Slettet: \\
\hline kirurgi for hoptimalisere biertesvilut. Det er motstridende data om ve & Slettet: $15 \%$ Goamin s $m$ [35] \\
\hline & Formatert \\
\hline preoperativ ekkokardiografi hos ikke-symptomatiske pasienter for jkke-kardial & Slettet: 8 \\
\hline kirurgi. & Slettet: liset and ... $2 . \ldots[37]$ \\
\hline Stresstes 1 kan avdekke koronariskgmi Patologisk stresstest. & Slettet: \\
\hline giennomfores wed fvisk anstrengelse eller ved medikamenter (dobs & Slettet: +40 \\
\hline ge tew & Slettet: E \\
\hline forutsi et problematisk perioperativt forlop. Normal stresstest kan predikere et & Slettet: ba \\
\hline kardialt vkomplisert forlop (1). Intervensionsbehandling med perkutan koronar & Formatert \\
\hline
\end{tabular}

Figur 1 Eksempel på redaksjonelle markeringer gjort i manuskriptet ved første gangs redaksjonell tilbakemelding på manuskript til invitert artikkel (7)

HVA KAN GJøRES?

Vi tror mye kan rettes med enkle grep. Acta Paediatrica har et bevisst forhold til tidsbruken mellom mottatt revisjon og akseptert manuskript, noe som gir en god og synlig intern og ekstern kvalitetskontroll på den redaksjonelle prosessen. Ut fra tabell 1 er halvparten av manuskriptene i Acta Paediatrica mottatt i revidert form innen 86 dager etter at de ble sendt inn, og halvparten av innsendte manus er akseptert 14 dager etter dette, sannsynligvis på det første redaksjonsmøtet etter mottatt revisjon. For å bevisstgjøre redaksjon og lesere bør også Tidsskriftet angi når det reviderte manuskriptet ble mottatt og akseptert. Samtidig bør man også være formelt strengere med manuskripter som heller ikke etter revisjon er akseptable. I slike tilfeller bør det gis beskjed om at manuskriptet må sendes inn på nytt etter ytterligere bearbeiding. 
Iveren etter å forme manuskriptet inn i en egen redaksjonell språklig stil bør tones kraftig ned. Etter vår mening skal en artikkel skrives av forfatteren med forfatterens språk og basert på forfatterens språkfølelse - den skal ikke skrives av medisinsk redaktør eller fagfelle. Dersom man i enkelte tilfeller mener at en god artikkel ikke holder tilstrekkelig høy språklig standard, kan man i siste instans vurdere bruk av profesjonelle «språkvaskere» der forfattere kun skal akseptere at budskapet er uendret.

Tabell 3 indikerer at det er store forskjeller mellom de medisinske redaktørenes effektivitet, noe som kan ha mange forklaringer. Redaksjonelt arbeid er ikke alltid like lett. Fagfeller og medisinske redaktører bør derfor sannsynligvis få bedre retningslinjer for arbeidet. Bedre instruksjoner koblet med krav til leveringstid bør inngå i Tidsskriftets personalpolitikk. Dersom fagfeller eller medisinske redaktører likevel ikke makter å gjøre det redaksjonelle arbeidet med tilfredsstillende tempo og kvalitet, bør man vurdere å rekruttere nye medarbeidere. For ytterligere å redusere publiseringstid bør Tidsskriftet som andre publikasjoner vurdere å publisere først på nettet (ahead of print). Redaksjonen i Tidsskriftet har i den senere tid også nedlagt betydelig arbeid med å videreformidle medisinske nyheter og resultater på en populærvitenskapelig måte i nettsteder som Facebook og Twitter. Dersom dette arbeidet trekker ressurser fra behandlingen av den rent faglige formidlingen, er det en utvikling Tidsskriftet, dets forfattere og lesere sannsynligvis ikke er tjent med.

\section{Konklusjon}

Tidsskriftet har en viktig funksjon i norsk medisin. Det bør være attraktivt å publisere der og Tidsskriftet bør aktivt stimulere erfarne forskere og klinikere til å bidra. En lang publiseringstid med arrogant holdning til forfatterens språkføring vil virke demotiverende. Det bør derfor gjøres noe med den redaksjonelle behandlingen av manuskripter. Vi tror at en kritisk gjennomgang av prosessen vil bidra til dette og håper vårt innlegg vil stimulere til en slik debatt, uten at det blir tatt som et angrep på personene i redaksjonen.

\section{Oppgitte interessekonflikter:}

Ingen

\section{LITTERATUR}

1. Odland JØ. Ikke oppdatert kunnskap om miljøgifter. Tidsskr Nor Legeforen 2010; 130: 261.

2. Teigen IM, Rendum KL, Slørdal L et al. Feilmedisinering hos pasienter innlagt på sykehus. Tidsskr Nor Legeforen 2009; 129: 1337-41.

3. Bratlid D, Farstad T. Persisterende ductus arteriosus hos for tidlig fødte barn. Tidsskr Nor Legeforen 2009; 129: 1455-8.

4. Størdal K. Hivsmitte fra mor til barn - kan epidemien stoppes? Tidsskr Nor Legeforen 2010; 130: 4802 .

5. Sellevold OF, de Hert S, Pelosi P. A major step forward: guidelines for the management of cardiac patients for non-cardiac surgery - the art of anaesthesia. Eur J Anaesthesiol 2010; 27: 89-91.

6. Sellevold OF, Guarracino F. Transcutaneous aortic valve implantation: recent advances and future. Curr Opin Anaesthesiol 2010; 23: 67-73.

7. Sellevold OF, Stenseth R. Ikke-kardial kirurgi hos hjertesyke pasienter. Tidsskr Nor Legeforen 2010; 130: 623-7. 
Publisert: 17. juni 2010. Tidsskr Nor Legeforen. DOI: 10.4045/tidsskr.10.0336

Manuskriptet ble mottatt 12.3. 2010 og godkjent 6.5. 2010. Medisinsk redaktør Erlend Hem.

(C) Tidsskrift for Den norske legeforening 2023. Lastet ned fra tidsskriftet.no 26. april 2023. 